\section{Media should campaign on the basis of facts}

SIR - Your Editorial on how the scientific community should respond to public controversies ("Responding to uncertainty" Nature 437, 1; 2005) suggested that researchers should attack, on a "scientific basis", misleading reports that appear in sections of the media. I would like to make some further points about the responsibilities of the media.

Certainly the media should be free to report the opinions of maverick researchers, no matter how unrepresentative these may be of the rest of the scientific community. After all, mavericks are occasionally right. But it is not in the public interest for the media to present these views in a way that creates a misleading impression about the amount of support they have among other scientists.

\section{"The scientific community should} make every effort to ensure that the media and public know where the weight of opinion lies."

\section{- Robert May}

As you point out, journalists often strive to achieve a balance by reporting one view and then presenting a diametrically opposed counter-view. When presented in the same way time after time, this can make the research community seem to be evenly divided, even if there are a thousand on one side and one on the other.

As researchers at Cardiff School of Journalism have shown, much of the public gained the wrong impression about how few scientists believed that the triple vaccine for measles, mumps and rubella (MMR), mentioned in your Editorial, was linked to autism and bowel disorders in children, partly because of campaigns in the media. Even more difficulties are created if there are many differing viewpoints.

But the real problems arise when parts of the media decide to campaign on an issue. To take some UK examples, such campaigns may be openly declared, as with attempts by The Sunday Times in the 1990s to convince its readers that HIV was not the likely cause of AIDS, and by The Independent on Sunday at present to promote the view that genetically modified (GM) foods pose an inherent danger to human health and to the environment. Or they may be undeclared: The Daily Mail, for example, seems to be running a campaign to deny the existence of a link between greenhouse-gas emissions and climate change.

In any country, such campaigns can mislead the public about where the weight of scientific opinion lies.

The scientific community should undoubtedly make every effort to ensure that the public and media know where the weight of scientific opinion lies on issues such as the MMR vaccine, GM foods, HIV and climate change. But surely the media also have a responsibility to find out and convey that information as well?

\section{Robert May}

The Royal Society, 6-9 Carlton House Terrace, London SW1Y 5AG, UK

\section{No evidence for Croatian race claims}

SIR - I reject the accusation of racism implicit in your News story ${ }^{\circ}$ Race daims spark fury over Croatia's school curriculum" (Nature 437, 463; 2005). Claims that I am getting teachers to "promote the view that Croats are only distantly related to other Slavic populations such as the Serbs" and that I believe "Croats are more similar to Finns than other Slavs" come from newspapers that misinterpreted my words. Such daims reflect neither my published research nor my subsequent statements and actions on this issue.

The Institute of Education and other authorities, not the minister of science and education, create details of the school curriculum in Croatia. It is up to them to determine which examples of applied science should be offered to Croatian students. Had $\mathrm{I}$, as minister of science and education, either approved or disapproved of the use of data from my scientific work, I could rightly have been accused of meddling. I did not, and any accusations are therefore unjustifiable.

I am deeply disappointed that Nature invited my colleagues and collaborators to comment on statements I never made. Your assertion that "scientists inside Croatia are cautious about engaging in public criticism" and its imlication about the democratic dimate in my country are neither true nor supported by any evidence.

\section{Dragan Primorac}

Ministry of Science, Education and Sports, Trg hrvatskihvelikana 6, 10000 Zagreb, Republic of Croatia

\section{Katrina: don't blame the Bush administration}

\section{SIR — Your Editorial “Small-minded} government" (Nature 437, 169; 2005) accuses the US government of failing to "protect its most vulnerable citizens" in the aftermath of Hurricane Katrina. The United States has a federal government, which means that the responsibility for citizen protection, and for first response after the hurricane, lies with the local state and city governments of Louisiana and New Orleans. We are not a dictatorship in which the national government can override local authorities.

Furthermore, your comment that US leaders may be forced to confront the poverty that was a contributing factor to the crisis after Katrina is unfair. You assume that everyone, given the opportunity, would want to compete in the marketplace to gain a level of economic success measured by an abundance of material goods. There is a limit to what the national government can do previous efforts have rarely been very successful. This country has drug, and similar, problems that primarily affect the poor, meaning they make poor choices that limit their own economic well-being. But President Bush and his administration have already done something to benefit all the people in this country, including the poor he has spearheaded the reduction in taxes to stimulate the economy.

The opinion expressed in your Editorial shows a lack of understanding, a judgemental attitude, and a disregard for the elementary rule of good scientific inquiry. It leaves me with a strongly held belief that foreigners generally know very little about this country, and that what they do know is garnered primarily from leftist, élitist news media and fictional movies.

\section{Stephen F.Larner}

Department of Neuroscience, Center for Traumatic Brain Injury Studies, McKnight Brain Institute of the University of Florida,

Box 100244, Gainesville, Florida 32610, USA

\section{Katrina revealed need for reform. Let's not forget it}

SIR - As an American, I am stunned by Nature's chutzpah in editorializing on the performance of the US government in response to Hurricane Katrina ( ${ }^{\circ}$ Smallminded government" Nature 437, 169; 2005). And as a patriotic citizen, I am gratified by the boldness of your statement and the insight of your critique.

I hope that our domestic technical publications and professional societies will join Nature in calling clearly for reform. In particular, the politically motivated abolition in 1995 of the Congressional Office of Technology Assessment was a costly mistake. The present disaster shows that ignoring warnings by technical professionals does not make problems go away.

\section{Alison Chaiken}

47 Esparito Avenue, Fremont,

California 94539, USA

Nature's Editorials are written by editorial staff. As in this case, writers include US citizens and others who have lived in the United States for years - Editor, Nature. 